ORIGINAL ARTICLE

\title{
Future perspectives as a condition of positive adaptation of young adults after traumatic experience
}

\author{
Marzanna Farnicka \\ Department of Psychology, Faculty of Education, Sociology and Health Sciences, University of Zielona Gora, Poland
}

BACKGROUND

The paper presents the results of a study on the possible role of sense of influencing one's life and expectations towards the future as a personal condition of adaptation. In accordance with the theory of formulation of temporal perspectives, these variables were assumed to be related to construction of the psychological reality of the subjects.

\section{PARTICIPANTS AND PROCEDURE}

The study involved 162 adults in two groups, with traumatic experience and without such experience, aged 18-35. The tools used in the study included: Rosenberg SelfEsteem Scale (SES), Boszkiewicz Questionnaire: Life Experience Questionnaire, events evaluation and expectations of changes in the future.
RESULTS

The study revealed significant differences between people from the two groups in the scope of self-evaluation, sense of influence on events and future expectations.

\section{CONCLUSIONS}

The results pointed to the need for adjustment of therapeutic and preventive treatment to future expectations, evaluation of events and the current stage of development, as indicated by personal conditions of adaptation.

\section{KEY WORDS}

event evaluation; expectations for the future; self-esteem; process of positive adaptation

CORRESPONDING AUthor - Marzanna Farnicka, Department of Psychology, Faculty of Education,

Sociology and Health Sciences, University of Zielona Gora, 2 Energetyków Avenue, 65-001 Zielona Góra, Poland, e-mail: farniccy@gmail.com

AUthors' CONTRIBUtion - A: Study design - B: Data collection - C: Statistical analysis - D: Data interpretation .

E: Manuscript preparation · F: Literature search · G: Funds collection

TO CITE THIS ARTICLE - Farnicka, M. (2014). Future perspectives as a condition of positive adaptation of young adults after traumatic experience. Current Issues in Personality Psychology, 2(3), 164-170. 


\section{BACKGROUND}

The family is a complex and integrated whole characterised by structured patterns of interactions. The existence and continuation of the family depend not only on biological genetic transfer but also on functioning at the psychological and social levels (McGoldrick \& Carter, 1989). Family functioning is based on the past experience of its members, affecting the hierarchy of values, norms and attitudes, transferred in the traditions, habits, adopted social roles, aspirations and expectations. The transferred message is vital for development of the family identity and development of its members. According to the theory of systemic family development, important factors affecting the psychological sphere are: activity of an individual, the impact of society and culture. Individual experience is gained through the activity of an individual in the family relations, in peer groups and in a broader social environment (the world of other people, objects, tasks and pressure). The relations force the response of an individual, which after processing by the psychological system are incorporated in the inner world of the individual (Pervin, 2003; Tyszkowa, 1988). Developmental changes occur firstly in the substructures of the individual's psychological system and then, as a result of changes in the inner system, lead to qualitative developmental changes in the entire psychological system of the individual. Subsequently, these changes are manifested in the functioning of a developing individual or in a family and they initiate developmental changes in this micro-system. This process can be called "the loop of developmental changes" because the changes created by acquired experience are the end of one cycle as well as the beginning of the next one. The assumption about the changes occurring over a period of time and the relations between events important in life, cultural pressure and the cycle of family development and individual development are the basis of a hypothesis that subsequent experiences, which result from the activity of an individual and rebuild his/her psychological system, may influence every participant of an interaction and even shift a family into the next cycles of its development (Erikson, 1980; McGoldrick \& Carter 1980; Giddens, 1991; Satir, 2000). On the basis of observation of functioning of some adults, their problems are related to the socalled "risk developmental environment". The indicators of a risk environment include a dysfunctional family with the presence of violence, sexual abuse, addictions of parents, orphanhood, terminal illness of a family member, removal of parental custody and living in a foster family or educational institution. The sources of vulnerability are psychosocial factors; an increased amount of negative life stress plays a role in the development of problematic behaviour among individuals from "problematic families". The effects of bad patterns are specifically related to a range of factors, such as: the unconscious process of identification and modelling, imitation of parental drinking habits, growth expectations associated with the consumption of alcohol and other negative aspects of the parent-child relationship (Chassin, Pillow, Curran, Molina, \& Barrera, 1993; Zucker, Kincaid, Fitzgerald, \& Bingham, 1995). This study is focused on factors connected with the multifactorial, dynamic process of dealing with adverse conditions, leading to the development of positive adaptation (Luthar, Cicchetti, \& Becker, 2000).

Positive adaptation is one of the key concepts essential for understanding the course of the development of children raised in inadequate living conditions. It refers to a multidimensional process in which the individual uses his/her mental capabilities and environmental resources to adapt to the requirements of the next phase of development. Positive adaptation is considered to be the product of mutual interaction between individual characteristics (biological and psychological), the history of previous adaptations, and development within the current phase of life and the environmental setting (Boyce et al., 1998; Sroufe, 1997; Cichetti, 2006).

This study aims to find similarities and differences in the area of creating prospects for the future between those who have suffered traumatic experience and those who have not.

Temporal orientations are often related to expected events to which an individual aspires. These events become the "signs of time" or breakthrough events. Their realisation contributes to building the sense of achievement (Malmberg \& Trempała, 1988; Liberska, 2002). According to Trempała, the temporal orientations are "...complex, cognitive and motivating conceptualisation of the individual's self-image in the future and/or about the context of future life" (Trempała, 2002, pp. 111-122). It assumes that the temporal perspective may designate different directions of the relationships between the past, present and future. The current state thus can be seen from the viewpoint of remembered past or the anticipated future. When considering the basic categories of temporal expectations, we have to focus on the context and the individual experience. The expected structures of experiences consist of the following components: the field of expected events in the next period of life (i.e. starting a family, the first job, starting or graduating from school), and the evaluation of expected events. Self-knowledge has been characterized by self-esteem and a sense of influence on one's own life. Trempala indicates that the individual experience is more important for the formation of these perspectives than the cultural one. 


\section{AIM OF THE STUDY}

From the perspective of the adopted model, it was assumed that the orientation towards the future is not only related to one's age and perceived normative events. In this study it is presumed that the process of shaping of the future prospects of the individual occurs through the gaining of experience, its structuring and restructuring - particularly in the area of self-knowledge and evaluation (Klauer, 2009). The subjects were divided into two groups depending on their social background. A crisis situation takes place when the perturbation of balance between a human being and the environment is so great that it is impossible to apply the usual means to re-establish it and it is necessary to seek other ways of functioning (Moos \& Schaefer, 1986; Kaplan, 2005). One of the features of a crisis situation is the fact that the usual patterns of action prove no longer possible to apply. The aim of this study was to explore the existence of a connection between evaluation of event influence, self-esteem, sense of influence on events and expectations for the future with the age of people participating in the study who underwent a traumatic experience. These were young adults coming from their natural families and young adults from foster care or other special education institutions. In the research process an attempt has been made to answer the following question: What are the differences and similarities between young adults from different family backgrounds in their self-esteem, sense of control and evaluation of events that influenced their life?

\section{PARTICIPANTS AND PROCEDURE}

\section{DESCRIPTION OF STUDY MEASURES}

The tools used in the study included: Life Experience Questionnaire - a tool studying the assessment of event influence on the life of an individual presented by Boszkiewicz (1997), the event evaluation based on the Trempala, Malmberg scale (1998), a tool investigating the spheres of expected changes in the form of a questionnaire and a tool investigating the expected time of the occurrence of events (Farnicka, 2011a), and the Self-description based on the Rosenberg (1965) scale.

The tool investigating assessment of event influence on the life of an individual is based on the Life Experience Questionnaire by Boszkiewicz (1997). The questionnaire comprises 20 questions concerning events from young adulthood. The respondents defined the importance of a particular event (e.g. first work, graduation from a school) on a 7-point scale, where ' 6 ' is extremely positive and ' 0 ' is extremely negative (Cronbach's $\alpha=.76$ ).

The tool for investigating expectation of changes in future (Farnicka, 2011a). The respondents defined the sphere of life in which they expected changes for better in the time of 1, 2 and 3 years. The spheres considered were that of personal development, that of family relations, professional development and health. They were also asked to estimate the probability of changes for better in particular spheres. On the scale from 0 to 5 , 0 means that life (in a particular sphere) will change for the worse, 1 means that it will not get better, 2 means that it will get slightly better, 3 means that it will get better, 4 means that it will get substantially better, and 5 means that it is definitely going to change for the better.

\section{PARTICIPANTS}

The study was performed on 162 individuals aged from 18 to 35, divided into two groups. The first group included people who claimed to have had no traumatic experience in their life and are from natural families $(n=89)$. The second group included people who claimed to have had traumatic experience in their life and who come from foster families $(n=73)$.

\section{PROCEDURE}

The first group was composed of people who did not experience traumatic situations in their families, and the second group comprised people who admitted having experienced traumatic events in their families. The study was divided into two stages. In the first stage the results concerning such variables as self-esteem, evaluation of event influence and expected changes in life were analysed within the two groups, while in the second stage the results obtained for the members of the two groups were compared.

\section{RESULTS}

\section{FUTURE EXPECTATION OF CHANGES}

Respondents from the control group expect positive changes in the perspective of 1,2 or 5 years. The most frequent answers indicated the expectation of changes in the sphere of family and financial situation. To the questions on the state of health and personal development the members of the control group usually responded "I do not know" and "My health will not change". The members of the study group most often responded: "I do not expect changes in this sphere of life". The statistical difference between the responses from the two groups was $\chi^{2}(1)=76.45, p=.001$.

\section{SELF-ESTEEM}

Respondents from the study group gave answers indicating that their self-evaluation in such areas as 
Table 1

Differences in self-esteem among groups

\begin{tabular}{|c|c|c|c|}
\hline $\begin{array}{c}\text { Categories } \\
\text { of self-description }\end{array}$ & $\begin{array}{c}\text { Average person without } \\
\text { diagnosed traumatic event }\end{array}$ & $\begin{array}{c}\text { Average person with } \\
\text { diagnosed traumatic event }\end{array}$ & Relevance $p$ \\
\hline Attractiveness & 2.98 & 2.61 & .246 \\
\hline Intelligence & 3.24 & 2.87 & $<.001$ \\
\hline Activity & 3.13 & 2.92 & .072 \\
\hline Sociability & 3.18 & 3.02 & .270 \\
\hline Sustainability & 3.54 & 3.18 & .020 \\
\hline Protectiveness & 3.66 & 3.13 & $<.001$ \\
\hline Responsibility & 3.72 & 3.18 & $<.001$ \\
\hline Intelligence & 3.24 & 2.87 & $<.001$ \\
\hline Self-confidence & 3.06 & 2.76 & .008 \\
\hline
\end{tabular}

intelligence, protectiveness, responsibility, independence and self-confidence was statistically significantly lower than that of the persons from the control group. In the dimensions such as attractiveness, activity and sociability associated with the operation of social relationships there were no significant differences (Table 1).

\section{THE SENSE OF INFLUENCING ONE'S LIFE}

As to the sense of influencing one's life, the persons from the control group had a much stronger sense of control over their life in the financial sphere, professional life, relations with partner, relations with other people and in the sphere of health. It should be emphasised that the young people from both groups have a similar level of evaluation of their looks, ways of spending free time and relations in families. The similarities and differences that were observed are presented in Table 2.

\section{THE SENSE OF INFLUENCE OF EVENTS ON ONE'S LIFE}

The respondents were asked to evaluate the influence of events treated as normative in the period of early adulthood on their life. These events included: the choice of partner, graduation from school, taking up the first job, involvement in social events and network, use of voting rights, religious involvement, promotion at work, job loss, serious improvement in financial standing. The results of the study indicate different evaluation of the importance of events connected with career and social activity. The members

Table 2

Similarities and differences in the sense of influencing ones' life

\begin{tabular}{cccc}
\hline $\begin{array}{c}\text { Categories of sense } \\
\text { of influence }\end{array}$ & $\begin{array}{c}\text { Person without diagnosed } \\
\text { traumatic event }\end{array}$ & $\begin{array}{c}\text { Person with diagnosed } \\
\text { traumatic event }\end{array}$ & Relevance $p$ \\
\hline $\begin{array}{c}\text { Financial status } \\
\text { Own health }\end{array}$ & 5.63 & 4.26 & .010 \\
$\begin{array}{c}\text { Professional life } \\
\text { Relationships with } \\
\text { a partner }\end{array}$ & 5.56 & 5.14 & .033 \\
$\begin{array}{c}\text { Relationships with other } \\
\text { people } \\
\text { Image }\end{array}$ & 6.60 & 4.61 & $<.001$ \\
$\begin{array}{c}\text { Relationships with family } \\
\text { Ways of spending leisure } \\
\text { time }\end{array}$ & 5.89 & 5.37 & .001 \\
\hline
\end{tabular}


of the studied group describe their influence as more positive (Table 3 ).

\section{DISCUSSION}

The aim of the study was to present the way of adaptation to the challenges of the modern world but also the tasks which are to be undertaken by the adults in the process of adaptation. It has been emphasized that in order to effectively develop one's own idea of life, one needs to previously anticipate the contents of life on a very detailed level (Liberska, 2002; Nurmi, Liiceanu, \& Liberska, 1999). According to the accepted model, it was assumed that the orientation towards the future is not only a resultant of the age and perceived normative events, but above all it is shaped in a particular socio-cultural reality as a subjective "theory of one's own life" and integrates the formulation of the concept of "I" (Trommsdorff, 1994; Malmberg \& Trempała, 1998).

In view of the above, the lack of expected changes may indicate the lack of conception of one's life in the future. This attitude may follow from the lack of a sense of control over one's life in given spheres of life which determine the undertaken activity. Both processes, control over one's life and self-evaluation, determine the sense of perpetration (Moos \& Schaefer, 1986). The need to construct the future seems to be a norm. However, people who are in crisis or are addicted do not think about the future; they just think about the present and are concentrated on current needs and aims. They make no effort to construct the reality in the future perspective. That is why their activity is limited to reacting passively to social or cultural pressure with no attempt at their active modification.

The differences in evaluation of the effect of events on one's life between the two groups and higher level of satisfaction with life in persons from the control group may follow from the different life experience, but may also relate to the mechanism of idealisation of the present life situation. The involvement of this mechanism is indicated by the results obtained from the persons coping with such developmental problems as addiction of parents, experience of traumatic events, low level of parental support, low self-control or tendencies to deviatory behaviour (Heitzeg, Nigg, \& Zucker, 2008). According to these results, the reduced level of future expectations and acceptance of fate are the elements of the processes of coping with life.

The study revealed significant differences between people of various environments of upbringing in the scope of self-evaluation and the sense of influence on events (Farnicka, 2011b; Liberska, 2002; Szczykutowicz, 2011) and of future expectations. The results showed the differences in evaluation of events connected with family life and work. The obtained high evaluation of events connected with family life may indicate the influence of the current pattern of normative values. The pattern is connected with the influence of the individuals and important groups (e.g. family), which are directly related and influence the process of the sense of normativity formation as well as the course of socialization of an individual and a group. Additionally, the responses of young

Table 3

Comparison of sense of influence of events on one's life between groups

\begin{tabular}{cccc}
\hline $\begin{array}{c}\text { Categories of event } \\
\text { influence evaluation }\end{array}$ & $\begin{array}{c}\text { Person without diagnosed } \\
\text { traumatic event }\end{array}$ & $\begin{array}{c}\text { Person with diagnosed } \\
\text { traumatic event }\end{array}$ & Relevance $p$ \\
\hline $\begin{array}{c}\text { Completion of education } \\
\text { process }\end{array}$ & 5.13 & 6.33 & $<.001$ \\
First job & 4.94 & 5.86 & $<.001$ \\
$\begin{array}{c}\text { Involvement in social } \\
\text { events and network }\end{array}$ & 4.04 & 5.57 & $<.001$ \\
$\begin{array}{c}\text { Usage of voting rights } \\
\text { Religious involvement }\end{array}$ & 3.31 & 4.05 & $<.001$ \\
Promotion at work & 4.15 & 5.13 & $<.001$ \\
Job loss & 4.92 & 5.75 & .018 \\
Moving to own apartment & 1.15 & 1.67 & .319 \\
$\begin{array}{l}\text { Serious improvement } \\
\text { of financial standing }\end{array}$ & 5.24 & 5.43 & $<.001$ \\
Choice of life partner & 5.76 & 6.29 & $<.001$ \\
Change of work & 5.13 & 5.74 & .330 \\
\hline
\end{tabular}


adults in the two compared groups differ significantly. They perceive themselves as less self-confident. They evaluate their intelligence as lower, and indicate less control over their professional life. Young adults positively approach events of influence on their educational and professional future activities; however, they are still in the educational system or are out of work. This situation may suggest wishful thinking, or positive expectations towards the future. These results may be perceived as developmental optimism or as a pattern adopted from the family or as an inadequate evaluation of events as an indicator that disturbs true evaluation of reality (Klauer, 2009). Extremely positive evaluation can be the reason for frustration when the reality is different from expectations.

On the other hand, good results in areas connected with social life (attractiveness, activity), controlling image, ways of spending leisure time and own health are very good information. It means that these areas could be important for them. The occurrence of changes may indicate a dynamic way of restructuring one's experience and an adequate way of coping with the situations of everyday life (Chichetti, 2006; Moos \& Schaefer, 1986; Satir, 2000; Pervin, 2003).

\section{PRACTICAL IMPLICATIONS}

The results provide a basis for drawing conclusions on the dynamic structure of risk factors and resources in human life. Finally, it is worth considering whether the similarities and differences between the results obtained for the two groups are related to the experienced trauma. According to health psychology, the positive way of coping with trauma takes place when there are no side effects.

The question whether - and if yes, how - people coming from a difficult family environment should be helped requires deep consideration. The fact of having experienced traumatic events in the period of childhood does not imply developmental problems in the period of young adulthood. The correcting work and prophylactics should be aimed at elevation of the personal abilities and professional abilities/skills in order to gain a sense of having control over one's life and future. Thus, in a wider view the research results should be included in providing help for people who have experienced traumatic events in the family, so as to support them in choosing adaptation strategies instead of preserving the first evaluation of an event.

Moreover, the research results encourage exploration of this problem and monitoring of changes occurring during the preventive and corrective treatment. The research and corrective treatment may complete the current knowledge and support new ways of activities in the preventive programmes for people who are in danger of becoming a victim.
In conclusion, it is worth noting the need to include young adults in prevention programmes and during diagnostic procedures as well as to take into account the specificities of the stage of development and monitor the changes occurring during the preventive and corrective treatment, which could be temporal perspectives and sense of control over one's life. The content and scope of these programmes should be drawn from knowledge of the relationships between the various risk factors, protective factors and developmental processes.

\section{RefERENCES}

Boszkiewicz, H. (1997). Validity and reliability of non classical tests in psychology. Bydgoszcz: WSP.

Boyce, W. T., Frank, E., Jensen, P. S., Kessler, R. C., Nelson, C. A., \& Steinberg, L. (1998). Social context in developmental psychopathology: recommendations for future research from the MacArthur Network on Psychopathology and Development. Development and Psychopathology, 10, 143-164.

Chassin, L., Pillow, D. R., Curran, P. J., Molina, B. S., \& Barrera, M. Jr. (1993). Relation of parental alcoholism to early adolescent substance use: a test of three mediating mechanisms. Journal of Abnormal Psychology, 102, 3-19.

Cicchetti, D. (2006). Development and Psychopathology. In: D. Cicchetti (ed.), Developmental Psychopathology: Theory and Method ( $2^{\text {nd }}$ ed., pp. 1-23). New York: Wiley.

Erikson, E. (1980). Identity and the Life Cycle. New York: Norton.

Farnicka, M. (2011a). The changes of realization developmental tasks - revolution or evolution? (p. 176). Zielona Góra: OWUZ.

Farnicka, M. (2011b). Young adults and parenting evaluation and expectation of parenting in different types of families. In: H. Liberska (ed.), Relations in marriage and family: genesis, quality and development (pp. 99-116). Bydgoszcz: Wydawnictwo Uniwersytetu Kazimierza Wielkiego.

Giddens, A. (1991). Modernity and Self-Identity. Self and Society in the Late Modern Age. Stanford, CA: Standford University Press.

Heitzeg, M., Nigg, J. T., Yau, W. Y., Zubieta, J. K., \& Zucker, R. (2008). Affective circuitry and risk for alcoholism in late adolescence: differences in frontostriatal responses between vulnerable and resilient children of alcoholic parents. Alcoholism Clinical and Experimental Research, 32, 414-426.

Kaplan, H. B. (2005). Understanding the concept of resilience. In: S. Goldstein, \& R. B. Brooks (eds.), Handbook of Resilience in Children (pp. 39-47). New York: Kluver Academic/Plenum.

Klauer, K. Ch. (2009). Spontaneous evaluations. In: F. Strack, \& J. Forster (eds.), Social Cognition: The 
Basis of Human Interaction (pp. 199-217). New York, London: Psychology Press.

Liberska, H. (2002). Life perspectives of adolescents in the context of social and economic changes in Poland. In: J. Trempała, \& L. E. Malmberg (eds.), Adolescents' future orientation. Theory and research (pp. 51-65). Frankfurt am Main, Berlin, Bern, Bruxelles, New York, Oxford, Wien: Peter Lang.

Luthar, S. S, Cicchetti, D., \& Becker, B. (2000). The Construct of Resilience: A Critical Evaluation and Guidelines for Future Work. Child Development, 71, 543-562.

Malmberg, L.-E., \& Trempała, J. (1998). Future planning, both at school and in other contexts: The case of Finnish and Polish general-secondary and vocational-school students. Scandinavian Journal of Educational Research, 42, 207-226.

McGoldrick, M., \& Carter, B. (1989). The changing family life cycle. A framework for family therapy. Boston: Allyn \& Bacon.

Moos, R. H., \& Schaefer, J. A. (1986). Life transitions and crises. A conceptual review. In: R. H. Moos (ed.), Coping with Life Crises: An Integrated Approach. New York: Plenum Press.

Nurmi, J. E., Liiceanu, A., \& Liberska, H. (1999). Future-oriented interests. In: F. A. Alsaker, \& A. Flammer (eds.), The Adolescent Experience. European and American Adolescents in the 1990s (pp. 85-98). Mahwah, New Jersey, London: Lawrence Erlbaum Associates, Inc.

Pervin, L. A. (2003). The Science of Personality. Oxford: Oxford University Press.

Rosenberg, M. (1965). SES. Princeton: Princeton University Press.

Satir, V. (2000). Rodzina. Tu powstaje człowiek [Family. The New Peoplemaking]. Gdańsk: GWP.

Szczykutowicz, A. (2011). Attitudes to life time plans about setting up family as presented by Belgians and Poles in their early adulthood. In: B. L. Kaczmarek, G. E. Kwiatkowska, \& K. Markiewicz (eds.), Youth Facing the Challenges of Globalization (pp. 151-164). Lublin: Wydawnictwo UMCS.

Trempała, J. (2002). Models of psychological time in the research on time perspectives. In: J. Trempała, \& L.-E. Malmberg (eds.), Adolescents' future-orientation: theory and research (pp. 111-122). Frankfurt am Main, Berlin, Bern, Bruxelles, New York, Oxford: Peter Lang Publishers.

Trommsdorf, G. (1994). Future time perspective and control orientation: social conditions and consequences. In: Z. Zaleski (ed.), Psychology of Future Orientation (pp. 39-62). Lublin: Towarzystwo Naukowe KUL.

Tyszkowa, M. (1988). Rozwój psychiczny jednostki jako proces strukturacji i restrukturacji doświadczenia [Psychological development of the individual as a process of structuration and restructuration of experience]. In: M. Tyszkowa (ed.), Rozwój człowieka w ciagu życia [Human development in life-span] (pp. 44-79). Warszawa: PWN

Zucker, R. A., Kincaid, S. B., Fitzgerald, H. E., \& Bingham, C. R. (1995). Alcohol schema acquisition in preschoolers: differences between children of alcoholics and children of nonalcoholics. Alcoholism: Clinical and Experimental Research, 19, 1-7. 